\title{
Research on the Relationship Between Corporate Governance Performance and Financing Cost Under the Background of ESG Theory
}

\author{
Chunhong Wang ${ }^{1, \mathrm{a}}$, Minru Zhao ${ }^{1, \mathrm{~b}}$, Zhenhua Zhang*1,c \\ ${ }^{1}$ School of Accounting, Guangdong University of Foreign Studies, Guangzhou, China
}

\begin{abstract}
Since the reform and opening up, China's economy has developed rapidly, the market economy is booming, and the financing demand of enterprises is also increasing year by year. As a new development concept, environmental, social and corporate governance (ESG) theory has become an important evaluation index for the future development of enterprises. How to achieve sustainable development has become a necessary challenge for enterprise financing. Based on ESG theory, this paper discusses the influence of corporate governance performance on financing cost, and studies the relationship between corporate governance performance and financing cost. Through the empirical analysis, this paper can draw a conclusion that good corporate governance performance can effectively reduce the financing cost. According to this conclusion, this paper puts forward some suggestions on corporate governance based on ESG rating system.
\end{abstract}

\section{INTRODUCTION}

Since the reform and opening up, China's economy has been developing at a high speed for more than 40 years, and its economic growth has reached new highs. However with the recession of the world economy, the growth rate of China's economy has slowed down, and the investment behavior of the capital side has become more cautious. There are two kinds of traditional financing methods, which are direct financing and indirect financing. Direct financing refers to the direct issuance of stocks or bonds by enterprises to complete financing, and indirect financing refers to the bank's lending to enterprises after absorbing private deposits. At present, the difficulty of enterprise financing is getting higher and higher. How to effectively reduce the financing cost has become a necessary challenge for the development of enterprises. At the same time, social requirements for corporate governance performance are also rising. In this context, if enterprises want to achieve sustainable development, they must simultaneously improve their governance performance and business development ability. The sustainable development ability of an enterprise, to a great extent, represents the development potential of the enterprise and can reflect the solvency of the enterprise to a certain extent. Therefore, there is a certain relationship between corporate governance performance and financing cost in theory. Nowadays, many studies have been carried out on the relationship between corporate governance performance and financing cost at home and abroad. However, due to the different market mechanisms and different research perspectives, the research results are often quite different [1].

With the gradual advancement of China's ecological civilization construction, the concept of environmental protection is deeply rooted in the hearts of the people. The essence of the development of ecological civilization is green development. The concept of green development represented by the concept of environment, society and corporate governance (ESG) has also attracted the attention of financial institutions. The ESG evaluation system is gradually taken as the main evaluation index to evaluate the sustainable development ability of enterprises, so as to reduce the loan risk. Therefore, it is of great significance to study the relationship between corporate governance performance and financing cost based on ESG theory. In this regard, this paper will take the nonfinancial enterprises in the new third board from 2014 to 2019 as research samples, based on ESG theory, analyze the relationship between corporate governance performance and financing costs, and put forward corresponding development suggestions [2-3].

\section{ESG THEORY}

Environment, social and governance (ESG) represents environmental protection, social responsibility and corporate governance in the process of investment, which is the foundation of social responsibility investment and the core of green investment. Traditional investment methods are difficult to ensure that investors can obtain long-term and stable returns. Therefore, in the process of investment decision-making, the ESG evaluation system is included in the scope of investigation, which can greatly reduce the investment risk and improve the future income [4].

a'18148907565@163.com, ${ }^{b} 1434498581 @ q q . c o m,{ }^{c}$ zhangzhenhua@gdufs.edu.cn 


\section{A. Environmental}

The environment in ESG theory focuses on the strength of environmental protection in the process of business operation, focusing on energy saving, resource utilization, renewable energy use, cooperation with environmental protection organizations and environmental protection training system of employees.

\section{B. Social Responsibility}

The social responsibility in ESG theory tends to focus on the social responsibility of enterprises, focusing on whether the business activities of enterprises are based on the long-term interests of society rather than pursuing the maximum profits of enterprises. In the process of seeking economic benefits, enterprises should abide by the relevant national regulations to ensure that the interests of other stakeholders are not infringed.

\section{Corporate Governance}

The core of corporate governance is to solve the principalagent challenge faced by enterprises. It is defined as: corporate governance is to establish a long-term and stable balance and cooperation system with the management of the company on the basis of fully considering the interests of all stakeholders such as the board of directors, shareholders, managers and employees, so as to maximize the company's economic performance Economic benefits and social benefits.

\section{The Relationship Among Environment, Social Responsibility and Corporate Governance}

ESG theory requires that the environment, people and business should be combined in the process of enterprise development. In order to achieve long-term and stable development goals, enterprises need to infiltrate the environment, social responsibility and corporate governance into the development concept of the company. "Environment" mainly emphasizes the impact of enterprise's environmental performance on the future corporate profits, focuses on the utilization of energy by enterprises, and focuses on the material basis of green development of enterprises. "Human" focuses on the important role of stakeholders in the process of enterprise operation, including labor relations, promotion system and enterprise attractiveness, and mainly considers the human basis necessary for enterprise development. "Business" focuses on the establishment of corporate governance system, focusing on the perfection of the board of directors system and senior management system, which is the only way for sustainable development of enterprises. To sum up, ESG theory is conducive to the healthy development of enterprises, and corporate governance is more intuitive to reflect the level of enterprise management, more concerned by investors, to a certain extent, has an impact on corporate financing. Therefore, based on ESG theory, this paper focuses on the relationship between corporate governance and financing costs [5].

\section{EMPIRICAL ANALYSIS}

\section{A. Establishment of Model}

According to the previous research results, we can analyze the influence of corporate governance performance on financing cost, which is mainly divided into the three aspects. Firstly, from the perspective of sustainable development theory, the long-term and healthy development of enterprises will directly affect their financing costs, and the main channel for the outside world to understand the development of enterprises is the performance of corporate governance. Secondly, from the perspective of stakeholder theory, The development of enterprises needs the input and participation of various stakeholders, so enterprises can not only pursue the maximum interests of shareholders in the development process, but also need to fully consider the stakeholders. However, in the process of enterprise development, the ecological environment damage and imperfect corporate governance will affect the vital interests of the relevant parties, thus reducing the social valuation of enterprises, affecting the financing cost and long-term benefits of enterprises. Thirdly, from the perspective of signal theory, the level of corporate governance will directly affect the financing cost of enterprises, and in this process, it will be affected by corporate governance information disclosure quality impact. Based on the above contents, this paper puts forward the hypothesis that there is an inverse relationship between corporate governance performance and financing cost, and puts forward the following formula:

$$
Y_{i t}=X_{i t} \beta+\gamma \times C_{i t}+I_{i}+T_{i}+e_{i t} .(1)
$$

In the formula (1), $Y_{i t}$ is the financing cost of enterprise $i$ at $t, C_{i t}$ is a series of indicators, such as the performance of corporate governance level at time $t$ and the degree of enterprise ESG disclosure, $X_{i t}$ is control variable, $I_{i}$ and $T_{i}$ represent individual effects and time effects that cannot be directly observed respectively.

However, the hypothesis only includes corporate governance performance and financing cost, but in the actual process, due to inertia and dynamic adjustment mechanism, the impact on financing cost will be lagging behind. If the relevant content is not considered, it will lead to a large deviation between the research results and the real situation, which will affect the authenticity and effectiveness of the research results. Therefore, the time lag term is introduced on the basis of formula (1), and the following formula is derived:

$$
Y_{i t}=L(\alpha)+X_{i t} \beta+\gamma \times C_{i t}+e_{i t}
$$

$L(\alpha)$ represents lag polynomial of financing cost. 


\section{B. Data Source and Index Design}

This paper will take the non-financial listed enterprises in the new third board from 2014 to 2019 as the research sample, excluding the stocks of ST and * ST in each year, and the corporate governance performance data will come from the website of public environmental assessment and guotai'an database. In the study, outliers outside the 5\% $95 \%$ quantiles of all variables were replaced. The quality of various variables selected in this study is shown in Table I .

Two proxy variables will be selected to represent the financing costs faced by enterprises. One is the debt to interest ratio $(F I)$, and the ratio between the sum of net capital expenditure and interest income and the sum of short-term debt and long-term debt; the other is to use Tobin $Q$ value (TQ) to represent the market valuation of enterprises. $T Q$ value usually refers to the ratio between the time value and the replacement value of an enterprise's assets, which can effectively measure the enterprise's market valuation. The higher the $T Q$ value is, the higher the market valuation of the enterprise is, the more recognized the enterprise is by investors, and the lower the cost of obtaining financing for the enterprise.

TABLE I. VARIABLE SETTING

\begin{tabular}{|c|c|c|}
\hline Variable & Variable type & Variable meaning \\
\hline FI & $\begin{array}{l}\text { Dependent } \\
\text { variable }\end{array}$ & The debt to interest ratio \\
\hline$T Q$ & $\begin{array}{l}\text { Dependent } \\
\text { variable }\end{array}$ & Tobin $Q$ value \\
\hline$E N V$ & Environment & Environment indicators \\
\hline$S O C$ & $\begin{array}{c}\text { Social } \\
\text { responsibility }\end{array}$ & Social responsibility indicators \\
\hline$C O P$ & $\begin{array}{c}\text { Quality of } \\
\text { environmental } \\
\text { information } \\
\text { disclosure }\end{array}$ & Corporate governance indicators \\
\hline$E I D$ & $\begin{array}{l}\text { Quality of } \\
\text { social } \\
\text { responsibility } \\
\text { information } \\
\text { disclosure }\end{array}$ & $\begin{array}{c}\text { Score of environmental information } \\
\text { disclosure }\end{array}$ \\
\hline$S R D$ & $\begin{array}{l}\text { Quality of } \\
\text { corporate } \\
\text { governance } \\
\text { information } \\
\text { disclosure }\end{array}$ & $\begin{array}{l}\text { Score of social responsibility } \\
\text { information disclosure }\end{array}$ \\
\hline$C G D$ & $\begin{array}{l}\text { Control } \\
\text { variable }\end{array}$ & $\begin{array}{l}\text { Score of corporate governance } \\
\text { information disclosure }\end{array}$ \\
\hline$R T A$ & $\begin{array}{l}\text { Control } \\
\text { variable }\end{array}$ & Return on total assets \\
\hline$R N A$ & $\begin{array}{l}\text { Control } \\
\text { variable }\end{array}$ & Return on net assets \\
\hline$C R$ & $\begin{array}{l}\text { Control } \\
\text { variable }\end{array}$ & Current ratio \\
\hline$Q R$ & $\begin{array}{l}\text { Control } \\
\text { variable }\end{array}$ & Quick ratio \\
\hline$N P G R$ & $\begin{array}{l}\text { Control } \\
\text { variable }\end{array}$ & 3-year net profit growth rate \\
\hline$A T$ & $\begin{array}{l}\text { Control } \\
\text { variable }\end{array}$ & Asset turnover \\
\hline
\end{tabular}

\begin{tabular}{|c|c|c|}
\hline LTA & $\begin{array}{c}\text { Control } \\
\text { variable }\end{array}$ & Logarithm of total assets \\
\hline$B L R$ & $\begin{array}{c}\text { Control } \\
\text { variable }\end{array}$ & $\begin{array}{c}\text { The benchmark lending rate of the } \\
\text { People's Bank of China for 1-3 } \\
\text { years }\end{array}$ \\
\hline
\end{tabular}

Under the background of ESG theory, corporate governance performance will also involve the content of environment and social responsibility, so in the actual research process, we need to effectively consider the environment and social responsibility, and then form ESG together with corporate governance. Therefore, in the specific analysis process, we should analyze the impact of the three dimensions of environment, social responsibility and corporate governance on corporate financing costs. Then in the actual research process, different scholars have different research perspectives on ESG performance, and the final corresponding performance results will be different. In this case, this paper will synthesize the existing research results, in-depth consideration and analysis of the following contents.

Firstly, from the perspective of ecological construction, the performance of enterprises in the three dimensions of environment, social responsibility and corporate governance will also have certain differences, and most enterprises will only perform relatively well in one or two dimensions, while the performance of other dimensions is relatively poor. Secondly, in the research, we not only need to study and analyze the various negative effects brought about by the daily operation of enterprises (such as water resources use, energy consumption, social responsibility performance), but also need to study and analyze the management measures in the process of enterprises' coping with environmental risks, social risks and corporate governance risks, especially the management measures related to the ecological environment dimension The existing management measures can reduce the related risk factors. Third, the openness and transparency of corporate and social information disclosure will also affect the performance of the three dimensions of the enterprise. For example, in the process of information disclosure, if there is a third-party organization with high public trust as the certification, then the social recognition of information disclosure and the quality of enterprise disclosure information will be improved.

\section{Estimation Results of Static Model}

After substituting various variables and data into formula (1), the static model estimation results in Table II are obtained.

TABLE II. STATIC MODEL ESTIMATION RESULTS

\begin{tabular}{|c|c|c|c|}
\hline Variables & \multicolumn{2}{|c|}{$F I$} & \multicolumn{2}{c|}{$T Q$} \\
\hline \multicolumn{3}{|c|}{ Related variables of corporate governance performance } \\
\hline$E N V$ & $0.172 * * * \quad(0.04)$ & $0.005 \quad(0.03)$ \\
\hline$S O C$ & $0.009 \quad(0.04)$ & $-0.007 \quad(0.02)$ \\
\hline$C O P$ & $0.048 \quad(0.18)$ & $0.210 * * \quad(0.11)$ \\
\hline$E N V \times E I D$ & $-0.008^{*}$ & $(0.00)$ & $-0.003 \quad(0.00)$ \\
\hline
\end{tabular}




\begin{tabular}{|c|c|c|}
\hline$S O C \times S R D$ & $\begin{array}{ll}-0.0004 \quad(0.00) \\
\end{array}$ & $\begin{array}{ll}-0.0002 \quad(0.00) \\
\end{array}$ \\
\hline$C O P \times C G D$ & $-0.003 \quad(0.01)$ & $-0.005^{*} \quad(0.00)$ \\
\hline \multicolumn{3}{|c|}{ Control variable } \\
\hline $\begin{array}{l}\text { Constant } \\
\text { term }\end{array}$ & $13.680^{* * *} \quad(1.99)$ & $10.440 * * * \quad(0.89)$ \\
\hline$R T A$ & $0.010 \quad(0.02)$ & $0.007 \quad(0.01)$ \\
\hline$R N A$ & $-0.009 \quad(0.01)$ & $-0.002 \quad(0.01)$ \\
\hline$C R$ & $-0.160 \quad(0.12)$ & $0.130 * * \quad(0.05)$ \\
\hline$Q R$ & $0.580^{* *} \quad(0.14)$ & $-0.040 \quad(0.06)$ \\
\hline$N P G R$ & $0.00001 \quad(0.00)$ & $0.0002 * * * \quad(0.00)$ \\
\hline$A T$ & $0.340^{*} \quad(0.18)$ & $0.023 \quad(0.007)$ \\
\hline LTA & $-0.590 \quad(0.08)$ & $-0.440 * * * \quad(0.04)$ \\
\hline$B L R$ & $0.380^{* * *} \quad(0.05)$ & $0.26^{* * *} \quad(0.02)$ \\
\hline
\end{tabular}

\section{Robustness Check}

It can be seen from Table II that there is a positive relationship between corporate governance performance and financing cost, that is, the higher the level of corporate governance, the lower the financing cost of enterprises, which is roughly the same as the actual operation performance of enterprises in the market. In addition, in terms of environment and social responsibility, the lower the enterprise is punished by the environment and the higher the degree of social responsibility performance, the financing cost of the enterprise will also be effectively reduced, but the impact is relatively weak relative to the level of corporate governance. However, since the research does not consider the dynamic lag change of enterprise financing cost, the research results may have some differences with the real results. In order to further suppress the research differences, we need to repeat the verification through formula (2), and finally obtain the results in Table III.

TABLE III. DYNAMIC MODEL ESTIMATION RESULTS

\begin{tabular}{|c|c|c|}
\hline Variables & $F I$ & $T Q$ \\
\hline \multicolumn{3}{|c|}{ Related variables of corporate governance performance } \\
\hline$E N V$ & $0.236 * * \quad(0.06)$ & $-0.032 * \quad(0.02)$ \\
\hline$S O C$ & $-0.001 \quad(0.08)$ & $0.012 \quad(0.03)$ \\
\hline$C O P$ & $-0.159 \quad(0.27)$ & $0.223 * * \quad(0.11)$ \\
\hline$E N V \times E I D$ & $-0.011 * * \quad(0.27)$ & $-0.005 * * \quad(0.00)$ \\
\hline$S O C \times S R D$ & $0.000 \quad(0.00)$ & $0.002 * \quad(0.00)$ \\
\hline$C O P \times C G D$ & $0.000 \quad(0.01)$ & $-0.003 \quad(0.00)$ \\
\hline \multicolumn{3}{|c|}{ Control variable } \\
\hline Constant term & $11.83 \quad(7.886)$ & $23.814 * * \quad(9.55)$ \\
\hline$R T A$ & $0.010 \quad(0.02)$ & $-0.017 * * \quad(0.01)$ \\
\hline$R N A$ & $0.000 \quad(0.01)$ & $-0.004 \quad(0.00)$ \\
\hline$C R$ & $0.03 \quad(0.16)$ & $0.072 \quad(0.04)$ \\
\hline$Q R$ & $0.450 * * \quad(0.21)$ & $0.076 \quad(0.05)$ \\
\hline$N P G R$ & $0.003 \quad(0.01)$ & $0.001 * * \quad(0.00)$ \\
\hline$A T$ & $0.190 \quad(0.25)$ & $-0.396 * * \quad(0.11)$ \\
\hline
\end{tabular}

\begin{tabular}{|c|c|c|}
\hline LTA & $-0.424 \quad(0.04)$ & $-0.533 * * * \quad(0.05)$ \\
\hline BLR & $0.099 * * \quad(0.04)$ & $-0.609 * * * \quad(0.04)$ \\
\hline $\begin{array}{c}\text { Lagged period } \\
\text { of dependent } \\
\text { variable }\end{array}$ & 1 period & 1 period \\
\hline \multicolumn{2}{|c|}{$* *, * * *$ indicate significant at the $10 \%, 5 \%$, and $1 \%$ levels, } \\
respectively
\end{tabular}

The results support the conclusion of formula (1), indicating that there is a positive relationship between the performance of formula governance and financing cost, and the impact of corporate governance performance on financing cost is more obvious than environmental and social value. On the one hand, this situation shows that there is an obvious relationship between corporate governance performance and financing costs and whether enterprises can achieve sustainable development; on the other hand, with the continuous promotion of ecological civilization construction, financial institutions are paying more and more attention to environmental punishment and social value of enterprises.

\section{Conclusion And Suggestion}

\section{A. Conclusion}

There is a negative correlation relationship between corporate governance performance and financing cost, that is, the higher the level of corporate governance, the lower the financing cost. With the continuous promotion of ecological civilization construction, financial institutions pay more and more attention to the environmental punishment and social value of enterprises.

\section{B. Suggestions}

Regulatory authorities should encourage and guide commercial banks to give more support to enterprises with good corporate governance, excellent environmental protection and social value. The government needs to promote the market supervision policy, improve the market key, build the information connection mechanism of environmental protection and regulatory departments, realize the sharing of data and information.

\section{REFERENCE}

1. Peng Fangchun, "On influential factors of SMEs financing: enterprise scale, operation years, and financing demand differences," 2011 International Conference on Computer Science and Service System (CSSS), Nanjing, 2011, pp. 23542357.

2. P. B. Suroaji, M. Ulilalbab, Iskandar, T. Hendrawan and N. Rachmana, "Model design and Electronic Service Guide (ESG) analysis for DVB broadcast on hybrid platform and unicast network," 2016 10th International Conference on Telecommunication Systems Services and Applications (TSSA), Denpasar, 2016, pp. 1-5.

3. Ding Jie, Shi Yang and Ding Feng, "Convergence properties of multi-innovation ESG algorithms for multi-input multi-output CARMA models," 2008 27th Chinese Control Conference, Kunming, 2008, pp. 270-274.

4. Lin Song and Jing Wu, "The confusion between Cost of capital and cost of financing and its harm," 2010 Second International 
Conference on Communication Systems, Networks and Applications, Hong Kong, 2010, pp. 102-105.

5. L. Zhai, "Impact of Board Characteristics on Debt Financing Costs," 2019 International Conference on Economic
Management and Model Engineering (ICEMME), Malacca, Malaysia, 2019, pp. 665-668. 